\title{
Is “E” really for everybody? Picture books for older readers in public libraries
} By Mikki Smith

\section{Abstract}

Picture books for older readers present challenges for libraries in terms of how best to provide access to them. These books often have an "E" on the spine to indicate that they are "easy" or for "everybody," and share lower shelves with a far greater number of picture books geared for the preschool and primary grade audience. However, this classification by format might encourage older readers to pass over these materials. At the same time, questions remain about the effectiveness of housing these picture books with juvenile fiction, or of creating separate collections. This article looks at how the picture book as a format and picture book collections are defined, as well as the variety of ways in which a small sample of picture books for older readers are currently being managed in public libraries.

Whether bedtime or cumulative stories, alphabet or counting books, picture books help very young children to understand the world in which they live, to develop a sense of the language and expand their vocabularies, and to learn about expected behaviors. These books for young children are often synonymous with "picture books." Take, for instance, the following description of picture books from Horning (1997): "Because picture books function best as a shared experience between a fluent reader and a pre-reader, generally an adult and a young child, in order for a picture book to find true success, it must be good enough to spark this symbiotic relationship" (p. 90). She explains that the texts of picture books are short not only because of their format (usually 32 pages), but also because "preschoolers simply have limits as to what they can and will take in” (p. 90).

The majority of the books in most public library picture book collections cater to a preschool audience. However, a significant number of the books in these collections appeal to children roughly between the ages of five and eight. Sullivan (2005) acknowledges this when he describes picture books as "generally designed for the preschool or primary grade child" (p. 35). With the exception of "easy" or "beginning" readers, which employ a controlled vocabulary and limited number of words per page and are usually treated as a separate collection, many of the picture books for these primary-grade children are also intended to be read aloud, and may prove challenging for beginning readers.

Jacqueline Woodson's Show Way (2005) is a good example. Though several reviews indicated an age range of five or six and up, it employs a rich vocabulary ("plantation," "muslin," "chokecherry"), and its context spans from slavery through the present day. On one spread, images of newspaper headlines and signs from the days of segregation ("Death to all race mixers!" and "Heaven is crying for justice") accompany the text. The fact that the book earned a Newbery Honor speaks to its sophistication. While the Newbery Medal terms and criteria state that "books for this entire age range [up to and including fourteen] are to be considered" (Association for Library Service to Children, 1987, Definitions section, no. 2), they also stipulate that the committee must base its decision primarily on the text: "Other aspects of a book are to be considered only if they distract from the text. Such other aspects might include illustrations, overall design of the book, etc.” (ALSC, 1987, Criteria section, no. 2). This disadvantages not only picture books, but also graphic novels and "hybrids" such as Brian Selznick's Caldecott Award-winning The Invention of Hugo Cabret (2007), in which portions of the story are told through illustrations. The Newbery criteria make the Honor awarded to Show Way especially significant.

Though Show Way's intended audience extends through upper elementary grades, as children develop the ability, as independent readers, to appreciate the richness of a book like this, they generally move away from picture book collections, instead focusing almost exclusively on juvenile fiction and nonfiction. Picture book collections are often housed on low shelving units, which are appropriate for very young children, and the books are frequently designated by an "E" on the spine. This "E" traditionally stood for "easy," though many libraries, in recognition of the fact that picture books can be complex, difficult, and experimental in nature, have shifted instead 
to the idea that "E" is for "everybody." Although "everybody" is preferable to "easy" as a descriptor for picture book collections, it could also be interpreted as the equivalent of a " $G$ " movie rating (for "general audiences"), suggesting that the materials are suitable for the very young. This interpretation among older children could reinforce the notion that picture books are "babyish.” Wolfenbarger \& Sipe (2007) suggest: "While [the separation of picture books in this way] is a logistic and accepted solution in some libraries, it often creates a barrier that upper elementary and middle school students won't cross” (p. 278).

This is not to suggest that older children will never self-select materials in the picture book format: biographies, folktales, books of poetry, and other works classified in nonfiction collections seem to hold their own against books in other formats with similar themes. Several titles by Peter Sís fall into this category, for instance, his picture book biography of Charles Darwin, Tree of Life (2003), or his picture book biography of Galileo Galilei, Starry Messenger (1996). Juvenile nonfiction books are published in a wide variety of sizes, and the taller shelving units are generally set up to

Over the last few years, publishers have been producing more and more picture books in which the concept or the subject or the length of the text were not meant for Preschoolers. Sometimes we put these books in with the chapter books and they never got checked out. Sometimes we put them in the picture book bins and worried about them.

Sometimes they were placed in the non-fiction and then nobody found them. Librarians throughout the Pacific Northwest have told me that they made a separate section in their children's room for these books. We have decided to follow their lead.

\section{Juneau Public Libraries website, 2008}

accommodate this variation. Picture books in these collections, then, can blend in with other oversized books. In juvenile fiction collections, another place where picture books for older readers are often found, picture books do not fare as well; there, these picture books must often rest on their fore-edges, so they stick out beyond the front edge of the shelves. Anecdotal evidence suggests that this, too, might create a barrier for older children, and that a few picture books for older readers scattered throughout a larger juvenile fiction collection will not circulate as well as either chapter books or other picture books.

Given the massive popularity of graphic novels and comics in libraries, the idea that picture books which have been described as "the integration of visual and verbal art” (Bishop and Hickman, 1992, p. 2) should have great appeal for older readers does not seem far-fetched. As Henry and Simpson (2001), advocates for picture books for older readers, explain: "The present generation of students has come of age surrounded by visual stimuli. They regularly watch with older students in the classroom, along with a wealth of articles describing effective ways to engage students through picture books; however, in public libraries, the same opportunities do not exist, so the placement of these books in library collections takes on greater importance, as does the knowledge of library staff about these titles, so that these books might be integrated into library programs, booklists, and regular reader's advisory.

What does the "picture book format" mean? Galda and Cullinan (2005) explain that picture books "tell a story, present a poem, or develop an understanding of a concept through a unique combination of text and art.... The content of picture books may be realistic, historical, factual, or fanciful; the format defines this genre" (p. 8). They add to their definition that, in picture books, "the illustrations are as important as the text in the creation of meaning - sometimes even more important” (p. 29). Ammon (1996) writes: "Common characteristics shared by most picture books include length (most are 32 pages long, but they can very from 24 to 64) and format (pictures usually fill the page space and generally the text 
is brief). This marriage of words and pictures makes the book complete" (p. x). These descriptions allow for a wide range of materials to be considered "picture books.”

Sís's most recent effort, The Wall (2007), which was both a Caldecott Honor Book and winner of the Robert F. Sibert Informational Book Medal in 2008, uses the picture book format. Voice of Youth Advocates (VOYA) reviewed The Wall with a suggested age range of eleven to fifteen (Beach, 2007). Wendy Lukehart (2007), in her review for School Library Journal, wrote that the book's themes "will resonate with teens" (p. 140). Horn Book (2007) indicated an intermediate, middle school, and high school audience (p. 13). This raises questions about where the book is most appropriately located in public libraries. To place the book in a juvenile collection that serves children through the elementary grades might mean that the potential teen audience will never see it.

Table 1 looks at the holdings of nine libraries in terms of thirteen picture books for older readers, including The Wall. Each of these titles, with the exception of David Macaulay's Black and White, received a review with a suggested age range of grade three or higher from at least one of the following review sources: Booklist, School Library Journal, Horn Book, VOYA, or CCBC Choices. (CCBC Choices suggested Black and White for ages $4-12$, and the title is frequently mentioned on bibliographies of picture books for older readers.) The libraries were chosen for a number of reasons. The Canton Public Library in Michigan was chosen because it has an "illustrated fiction" section that includes many of the titles examined here, and this promised to provide a useful contrast to libraries with traditional picture book, juvenile fiction, and juvenile nonfiction collections. Duluth, Kenton County, Monterey, Racine, Urbandale, and Iowa City all have collection development and/or selection policies online for reference, though in some cases, the policies were too general to merit individual mention here. There was also immediate access to the collections of the Iowa City Public Library, which is where many of these picture books were checked out directly. The Des Moines Public Library is the largest library system represented (the only library with a service population of more than 200,000), while Worthington rounded out another of the service population categories. Of the nine libraries, three have service populations between 29,000 and 59,999; three have service populations between 60,000 and 89,999; and three have service populations greater than 90,000. (Service population data came from the Library Statistics Program, U.S.
Department of Education. Institute of Education Sciences, National Center for Education Statistics.) The purpose in looking at where specific libraries have chosen to place specific titles is not to question these decisions, as they are undoubtedly sound in the context of those communities and collections, but rather to provide a snapshot of what is happening in libraries as this eclectic group of picture books pushes the boundaries of a genre traditionally defined by format (Galda \& Cullinan, 2005). It is likely that any small sample of public libraries in the country drawn from those with youth collections of a decent size would yield similar findings.

(See Table 1 on page 12: Sample of holdings and locations for picture books for older readers as of early February, 2008)

In library systems with branches, only the holdings of the branch specified are considered here. "N/A" means that a title is not held in a library or branch collection. Though the designations of "E" and "Picture Book" are, in practice, synonymous, the form is kept closest to its appearance in that library's online catalog, since one could argue that the choice of designation is significant ("easy" or "everybody" for "E," which implies content, vs. "Picture Book," which describes the format). The Duluth Public Library, however, gives a location of "Picture book bins" for its picture book collection, but assigns a call number beginning with "J" rather than " $\mathrm{E}$ " to items (Pink and Say, for instance has the call number "J Polacco"); for this reason, "Picture Book" is used rather than "E" in this case. Their chapter books are given a call number of "Juv Fic," as are the picture books placed in this collection, so they are designated "Juvenile Fiction" in the table. Note that some libraries have opted to indicate a picture book's "older reader" appeal with a special spine label, similar to genre labels, though this indicator might not be replicated in the online bibliographic record. It is possible, then, that such indicators exist on the physical items at libraries represented in Table 1, though no evidence of this practice was found on their Web sites or in their catalogs.

A look at these nine public libraries revealed that, of the seven libraries that owned The Wall at the time of this writing, all chose to place the book within their juvenile nonfiction collections. Several of these libraries clearly define these collections to include books for middle school and, in fewer cases, high school students, so the potential older audience for the book should find it where they are accustomed to browsing nonfiction. Other libraries have both a juvenile and young adult nonfiction collection, so, depending on the layout of the library (if the children's materials are in a different room than young adult and adult materials, for instance), the juvenile location might prevent teens from spotting the book while browsing, and inhibit them from looking for it on the shelves if the 
record is retrieved in a catalog search. For example, on the "Children's Room Collections" page of the Iowa City Public Library (ICPL) Web site, the juvenile nonfiction section is described as "information books for preschool through fourth grade. Non-fiction for fifth- to eighth-grade is interfiled with adult non-fiction shelved on the second floor" (ICPL, 2008, Non-fiction section).

The question raised for libraries with juvenile nonfiction collections that serve children in the elementary grades is how to ensure that teens who might be interested in juvenile nonfiction books such as The Wall, either for their subject matter, their artwork, or the interplay of the two, actually come across them, since they live in a section that this patron group might not gravitate toward without encouragement. Additionally, in some cases children's staff might not be in regular contact with teen patrons, whose collections and choice seating areas might be elsewhere in the library. Making other staff aware of titles such as The Wall and finding ways to promote them across the library can help to ensure that older children, who will be able to appreciate the richness and sophistication of these titles, feel invited to do so.

Four of the books on the list of titles surveyed (I Never Knew Your Name, Patrol: An American Soldier in Vietnam, Rose Blanche, and Woolvs in the Sitee), though classified as "[Fic]" in their Cataloging in Publication (CIP) records, were classified in juvenile nonfiction by at least one of the nine libraries reviewed here. I Never Knew Your Name (Garland \& Greenberg, 1994) is in some ways the least typical of these. In it, a young boy of nine or ten tells the neighbor, a high-school student who recently committed suicide, about how he wishes they could have been friends. Five of the libraries examined owned the book (though, as an older title, other libraries may have owned it at one time), yielding four different locations. Two libraries include the book in their juvenile fiction collections; one has it in the picture book collection; one has it in juvenile nonfiction at 362.28 (suicide); and the Des Moines Public Library places the book, interestingly, in its Parents Collection.

Rose Blanche (Innocenti \& Gallaz, 1985) is the story of a German girl who sneaks food to the prisoners on the other side of the barbed wire during the Second World War, until one day (her last), she is shot by soldiers. Three libraries place this in their juvenile nonfiction collections (940); three place it in their juvenile fiction collections; and one library, ICPL, classifies it "E" and places it with the picture books. As a general rule, ICPL treats format rather than content as the determining factor when dealing with picture books, including those for older readers, which helps to explain why Woolvs in the Sitee (Wild \& Spudvilas, 2007), an Australian picture book with "fear" and "horror stories" as subject headings, can exist in the picture book collection at ICPL, the teen fiction collection at Worthington Libraries, and the juvenile nonfiction collection (at 398.47) at the Canton Public Library (CPL).

Patrol: An American Soldier in Vietnam, by Walter Dean Myers with illustrations by Ann Grifalconi (2001), describes in sparse language the experiences of a young American soldier who is in search of and must confront his "enemy." When confronted by a young Vietnamese soldier, he says: "I know he wants me to lift my rifle, to be the enemy. / I want him to lift his rifle. / I want him to turn away. / In a heartbeat, we have learned too much about each other." On the next spread, the narrator does raise, then lower, his rifle. In the end, the soldier expresses his utter exhaustion and despair, which is reflected in the accompanying illustration: "I am so very tired of this war." All of the libraries examined held this book, four in juvenile fiction and four in juvenile nonfiction. Two of the latter libraries treated the book as a poem (811), while two treated it as history (959). The remaining library, CPL, includes Patrol - along with Black and White (Macaulay, 1990), Pink and Say (Polacco, 1994), Show Way (Woodson \& Talbott, 2005), Wee Winnie Witch's Skinny (Hamilton \& Moser, 2004), and Wolves in the Walls

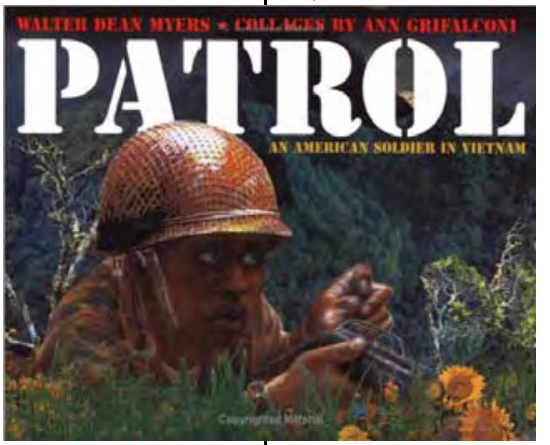

(Gaiman \& McKean, 2003) - in a section it calls "J Illustrated Fiction," described on its Web site as "a great collection of picture books for older readers” (CPL, [2008], CPL Children's Bookstacks section). Juneau Public Libraries (JPL) has apparently made a similar move, according to the "Sandra Says” portion of their Web site:

Over the last few years, publishers have been producing more and more picture books in which the concept or the subject or the length of the text were not meant for Preschoolers. Sometimes we put these books in with the chapter books and they never got checked out. Sometimes we put them in the picture book bins and worried about them. Sometimes they were placed in the non-fiction and then nobody found them. Librarians throughout the Pacific Northwest have told me that they made a separate section in their children's room for these books. We have decided to follow their lead. (JPL, [2008]) 
CPL and JPL represent here a trend that hopefully will be written about in forthcoming professional literature to help public libraries and school libraries that might be considering this move to make the best decision for their patrons and their space.

From a purely promotional standpoint, a separate, small collection of juvenile "illustrated fiction" has a great deal of potential. This would free these books from the low picture book shelves where the thousands of other titles for younger children live, while at the same time, make them look less awkward than they do sticking out in the juvenile fiction collection. However, one concern that has been voiced about this arrangement is that it could open the door to increased requests to remove materials from "E" picture book collections. If picture books for older readers are shelved in a separate collection, then this might lead some in the community to assume that the main picture book collection truly is " $E$ " for "everybody" (in other words, not likely to offend anyone). Patrons might begin to question why certain materials - for instance, the often challenged And Tango Makes Three (Richardson, Parnell, \& Cole, 2005) - are not placed with the more "mature" picture books in the other collection, though Tango is intended and appropriate for a preschool/primary grade audience. To find additional libraries that handle these materials similarly to the Canton Public Library and to determine whether librarians feel increased pressure to move certain materials into the special collection for older readers would be an important area for study. It would be essential, too, to see whether the separate collection of picture books for older readers actually results in increased circulation of those titles. Finally, are the readers of these picture books also chapter book readers? Do they prefer picture books generally? Are they graphic novel fans?

Although many libraries are able to place titles such as Patrol in their juvenile nonfiction collections, some titles do not lend themselves to such classification, making the idea of a separate collection appealing. The Watertower, an Australian import by Gary Crew with illustrations by Steven Woolman (1998), is a creepy science fiction story, in which a mysterious watertower dominates the landscape of the small town of Preston. The book is sophisticated enough in language, style of illustration, and format (the orientation of the text on the page shifts as the story unravels, so the book must be turned in order to be read) that a more sophisticated reader would find more to appreciate in the details and the ways in which the language and illustrations are used to create the mood than younger children. Six of the libraries reviewed do not own The Watertower, and of the remaining three, two placed it in Juvenile Fiction, despite its CIP classification "[E]", while ICPL placed it in its picture book collection. The Composition (Skármeta \& Ruano, 2000), the story of nine-year-old Pedro's developing understanding of what it means to live under a dictatorship, and Just One Flick of the Finger (Lorbiecki \& Diaz, 1996), a story about bullying and gun violence, also skewed toward juvenile fiction. The former title is in four juvenile fiction collections and one picture book collection, while the latter is in three juvenile fiction collections.

Not including Canton, Gaiman's Wolves in the Walls was represented in four picture book collections and four juvenile fiction collections (including one library with copies in each location), as well as in the Monterey Public Library youth graphic novel collection. Wee Winnie Witch's Skinny was placed in the picture book collection of a single library from those surveyed. Six libraries placed it with juvenile fiction (one inside the Holiday collection), one did not own the book, and Canton placed it with the illustrated fiction.

Patricia Polacco's devastating Civil War story Pink and Say (1994), based on an allegedly true story passed down through generations in her family, describes the friendship that develops between a black teen (Pink) and a white teen (Say) who are eventually sent to the Confederate camp at Andersonville as prisoners. While Say, Polacco's relative, survives the horror, Pink is hanged. All nine of the libraries own Pink and Say. Despite the weighty emotional and historical themes, six libraries place the book by format in the picture book collection, only two place the book in juvenile fiction, and Canton includes it in its illustrated fiction collection. The decision of the Duluth (Minn.) Public Library to include Pink and Say in the picture book collection is interesting in light of the library's collection development policy. The section defining the picture book collection states that in cases where "subject, style, illustrations and language are developmentally more appropriate for readers over the age of eight ... content takes precedence over format, and the books are usually placed in the Juvenile Fiction collection" (Duluth Public Library [DPL], 2006). The juvenile fiction section, on the other hand, is defined as containing books "of current interest as well as classics for independent readers from about grades two through six" (DPL, 2006). A case could be made that Pink and Say can be shared successfully with children under the age of eight; many reviews suggested age ranges of five, six, or seven and up, and DPL is in excellent company based on the other libraries examined here in its decision to place this book in its picture book collection. The Monterey 
Public Library (MPL) decision to place Pink and Say in its juvenile fiction collection is also interesting, since its policy explicitly clears the way for picture books with mature themes to remain in the picture book collection: "The picture book collection consists of titles for all ages in which illustrations are an essential part of the presentation. While many are designed for preschoolers, some are more appropriate for older children" (MPL, 2007, section X, part B). Despite the latitude granted by the policy, of the eight items MPL owns, only two of them are located in the "E" collection. Perhaps one factor in deciding where to place a picture book such as Pink and Say is whether it will be shared primarily between an adult and a child, or whether its primary audience will be independent child readers.

The Urbandale (Iowa) Public Library (UPL) defines its picture book collection as "board books, wordless books, concept books (alphabet, numbers, colors, shapes), classic and contemporary preschool picture book stories and fairy or folk tales” (UPL, 2003, Children's materials section). At the same time, Wolves in the Walls, Black and White, Pink and Say, and Show Way - none of which are easily characterized as "preschool picture book stories" - are all located in the picture book collection. Eight of the titles examined were not owned by the library at the time of this writing, and it would be interesting to explore to what extent the collections as defined by the policy influence the library's commitment to purchasing picture books for older readers. It should also pointed out, however, that Urbandale is the smallest of the nine libraries, so it is not surprising that its collection would be relatively smaller and more focused.

As the varied placement of these titles within library collections indicates, even when a fairly straightforward policy is in place that defines the scope of library collections, the best home for these picture books for older readers is rarely obvious. Libraries, even CPL with its illustrated fiction collection, appear to look at each picture book for older readers individually to determine where the item best belongs, with decisions driven by a desire to make the materials most accessible to their intended audience.

No matter how or where these individual titles are classified and located on the shelves and in the catalog, there are several things that librarians can do to spread the word about these titles to patrons. First, librarians can routinely use picture books for older readers in booktalks. Why not follow a teaser for the newest 700page fantasy novel with one for an unpaged picture book volume that is equally interesting? Librarians could also facilitate exploration of these titles by creating and promoting booklists that either include picture books along with other formats or that focus exclusively on picture books for older readers. If a special collection of materials is out of the question, perhaps a highly visible display featuring these items and enticing older child readers to check them out would be a possibility.

All signs indicate that picture books for older readers will continue to be published in greater numbers, and with authors such as Walter Dean Myers experimenting with the format, these books will continue to receive critical attention. Insofar as libraries collect them, they must also be willing to promote them and to make them easier to spot by the skeptical eleven-year-old who will spend no more time than she needs to browsing the picture book collection. There are some amazing, heartbreaking, and sophisticated works that fall into this category - but if they are not actively promoted, chances are the titles will gather dust on library shelves.

\section{Children's Books Cited}

Crew, G., \& Woolman, S. (1998). The watertower. Brooklyn, NY: Crocodile Books.

Gaiman, N., \& McKean, D. (2003). The wolves in the walls. New York: HarperCollins.

Garland, S., \& Greenberg, S. (1994). I never knew your name. New York: Ticknor \& Fields.

Hamilton, V., \& Moser, B. (2004). Wee Winnie Witch's Skinny: An original African American scare tale. New York: Blue Sky Press.

Innocenti, R., \& Gallaz, C. (1985). Rose Blanche. Mankato, MN, USA: Creative Education.

Lorbiecki, M., \& Diaz, D. (1996). Just one flick of a finger. New York: Dial Books.

Macaulay, D. (1990). Black and white. Boston: Houghton Mifflin.

Myers, W. D., \& Grifalconi, A. (2001). Patrol: An American soldier in Vietnam. New York: HarperCollins.

Polacco, P. (1994). Pink and Say. New York: Philomel Books.

Richardson, J., Parnell, P., \& Cole, H. (2005). And Tango makes three. New York: Simon \& Schuster Books for Young Readers.

Selznick, B. (2007). The invention of Hugo Cabret. New York: Scholastic Press.

Sís, P. (1996). Starry messenger: A book depicting the life of a famous scientist, mathematician, astronomer, philosopher, physicist, Galileo Galilei. New York: Farrar Straus Giroux.

. (2003). The tree of life: A book depicting the life of Charles Darwin; Naturalist, geologist \& thinker. New York: Frances Foster Books. 
(2007). The wall: Growing up behind the Iron Curtain. New York: Frances Foster Books.

Skármeta, A., Amado, E., \& Ruano, A. (2000). The composition. Toronto: Groundwood Books.

Wild, M., \& Spudvilas, A. (2007). Woolvs in the sitee. Asheville, NC: Front Street.

Woodson, J., \& Talbott, H. (2005). Show way. New York: G. P. Putnam's Sons.

Other Works Cited

Ammon, B. D., \& Sherman, G. W. (1996). Worth a thousand words: An annotated guide to picture books for older readers. Englewood, CO: Libraries Unlimited.

Association for Library Service to Children. Terms and criteria: John Newbery Medal. Retrieved January 31, 2008, from http://www.ala.org/ala/alsc/awardsscholarships/ literaryawds/newberymedal/newberyterms/newberyterms.htm.

Beach, K. (2007). [Review of the book The Wall]. Voice of Youth Advocates, 30(5).

Bishop, R. S., \& Hickman, J. (1992). Four or fourteen or forty: Picture books are for everyone. In Susan Benedict and Lenore Carlisle (Eds.), Beyond words: picture books for older readers and writers. Portsmouth, N.H.: Heinemann.

Canton Public Library. ([2008]). CPL Children's Bookstacks. Retrieved February 8, 2008, from http://cantonpl.org/kids/tour/bookstx.html.

Duluth Public Library. (2006). Collection development policy: Youth services. Retrieved February 6, 2008, from http://www.duluth.lib.mn.us/Policies/YouthServices.html.

Galda, L., \& Cullinan, B. E. (2005). Literature and the child. Belmont, CA: Wadsworth/Thomson Learning.

Henry, R., \& Simpson, C. (2001). Picture books \& older readers: A match made in heaven. Teacher Librarian, 28(3). Retrieved July 17, 2007, from Academic Search Elite database.

Horn Book fanfare: Our choices for the best books of 2007. Horn Book 84(1).

Horning, K. T. (1997). From cover to cover: Evaluating and reviewing children's books. New York, NY: HarperCollins.

Juneau Public Libraries. ([2008]). Sandra says: Juvenile illustrated fiction. Retrieved February 8, 2008, from http://www.juneau.org/library/kids/jif.php.

Lukehart, Wendy. (2007). [Review of the book The Wall]. School Library Journal, 53(8), 139-140.

Monterey Public Library. Collection development policy. Retrieved February 8, 2008, from http://www.monterey.org/library/cdp/cdp1.html.

Sullivan, M. (2005). Fundamentals of children's services. Chicago: American Library Association.

Urbandale Public Library. (2003). Collection development policy. Retrieved February 8, 2008, from http://www.urbandalelibrary.org/CollectionDevelopmentPolicy.html

Wolfenbarger, C., \& Sipe, L. (2007). A unique visual and literary art form: Recent research on picturebooks. Language Arts, 84(3), 273-280.

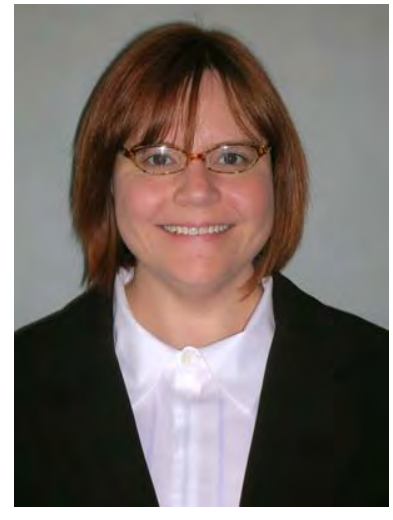

Mikki Smith is a

Reference/Technical Services Librarian at Cornell College in Mt. Vernon, Iowa, which also serves the Mt. Vernon community. She graduated from the School of Library and Information Science at the University of Iowa in July 2007, and also earned a graduate certificate in Book Studies from the UI Center for the Book. Among her interests are the history of children's literature, past and current trends in publishing for children and young adults, and issues related to library services for young people.

smimikki@gmail.com

Table 1 KEY:

$\mathrm{CPL}=\quad$ Canton (Mich.) Public Library

DMPL $=$ Des Moines (Iowa) Public Library - Central Library

DPL $=$ Duluth (Minn.) Public Library - Main

ICPL $=\quad \begin{array}{ll}\text { Library } \\ \text { Iowa City (Iowa) Public Library }\end{array}$

KCPL $=$ Kenton County (Ken.) Public Library Mary Ann Mongan Covington Branch

MPL $=$ Monterey (Calif.) Public Library

RPL $=\quad$ Racine (Wisc.) Public Library

UPL $=$ Urbandale (Iowa) Public Library

$\mathrm{WL}=$ Worthington (Ohio) Libraries - Old Worthington Library 
Table 1:

Sample of holdings and locations for picture books for older readers as of early February 2008

\begin{tabular}{|c|c|c|c|c|c|c|c|c|c|}
\hline \multicolumn{10}{|c|}{ LIBRARY } \\
\hline TITLE & CPL & DMPL & DPL & ICPL & KCPL & MPL & RPL & UPL & WL \\
\hline $\begin{array}{c}\text { Black and } \\
\text { White } \\
\text { (Macaulay) }\end{array}$ & $\begin{array}{c}\mathrm{J} \\
\text { Illustrated } \\
\text { Fiction } \\
\end{array}$ & $\begin{array}{l}\text { Picture } \\
\text { Book }\end{array}$ & $\begin{array}{l}\text { Picture } \\
\text { Book }\end{array}$ & J Caldecott* & $\mathrm{E}$ & $\mathrm{E}$ & $\begin{array}{l}\text { Picture } \\
\text { Book }\end{array}$ & $\mathrm{E}$ & $\begin{array}{l}\text { Picture } \\
\text { Book }\end{array}$ \\
\hline $\begin{array}{c}\text { The } \\
\text { Composition } \\
\text { (Skármeta) }\end{array}$ & N/A & $\begin{array}{l}\text { Children’s } \\
\text { Fiction }\end{array}$ & N/A & $\begin{array}{l}\text { Juvenile } \\
\text { Fiction }\end{array}$ & E & N/A & $\begin{array}{l}\text { Juvenile } \\
\text { Fiction }\end{array}$ & N/A & $\begin{array}{l}\text { Juvenile } \\
\text { Fiction }\end{array}$ \\
\hline $\begin{array}{l}\text { I Never Knew } \\
\text { Your Name } \\
\text { (Garland) }\end{array}$ & N/A & $\begin{array}{l}\text { Parents } \\
\text { Collection }\end{array}$ & N/A & $\begin{array}{l}\text { Juvenile } \\
\text { Fiction }\end{array}$ & $\begin{array}{l}\text { Juvenile } \\
\text { Fiction }\end{array}$ & N/A & $\begin{array}{l}\text { Picture } \\
\text { Book }\end{array}$ & N/A & J 362.28 \\
\hline $\begin{array}{c}\text { Just One Flick } \\
\text { of a Finger } \\
\text { (Lorbiecki) }\end{array}$ & N/A & N/A & N/A & $\begin{array}{l}\text { Juvenile } \\
\text { Fiction }\end{array}$ & N/A & N/A & $\begin{array}{l}\text { Juvenile } \\
\text { Fiction }\end{array}$ & N/A & $\begin{array}{l}\text { Juvenile } \\
\text { Fiction }\end{array}$ \\
\hline Patrol (Myers) & $\begin{array}{c}\mathrm{J} \\
\text { Illustrated } \\
\text { Fiction } \\
\end{array}$ & $\begin{array}{l}\text { Children’s } \\
\text { Fiction }\end{array}$ & $\begin{array}{l}\text { Juvenile } \\
\text { Fiction }\end{array}$ & J 811 & $\begin{array}{l}\text { Children’s } \\
959.7043\end{array}$ & J 811.54 & $\begin{array}{l}\text { Juvenile } \\
\text { Fiction }\end{array}$ & $\begin{array}{l}\text { J } 959 . \\
70433\end{array}$ & $\begin{array}{l}\text { Juvenile } \\
\text { Fiction }\end{array}$ \\
\hline $\begin{array}{l}\text { Pink and Say } \\
\text { (Polacco) }\end{array}$ & $\begin{array}{c}\mathrm{J} \\
\text { Illustrated } \\
\text { Fiction }\end{array}$ & $\begin{array}{l}\text { Picture } \\
\text { Book }\end{array}$ & $\begin{array}{l}\text { Picture } \\
\text { Book }\end{array}$ & $\mathrm{E}$ & $\mathrm{E}$ & $\begin{array}{l}\text { Juvenile } \\
\text { Fiction }\end{array}$ & $\begin{array}{l}\text { Juvenile } \\
\text { Fiction }\end{array}$ & $\mathrm{E}$ & $\begin{array}{l}\text { Picture } \\
\text { Book }\end{array}$ \\
\hline $\begin{array}{c}\text { Rose Blanche } \\
\text { (Innocenti) }\end{array}$ & J 940.5316 & N/A & $\begin{array}{c}\mathrm{J} 940.5318 \\
* *\end{array}$ & $\mathrm{E}$ & $\begin{array}{l}\text { Juvenile } \\
\text { Fiction }\end{array}$ & $\begin{array}{l}\text { Juvenile } \\
\text { Fiction }\end{array}$ & $\begin{array}{l}\text { Juvenile } \\
\text { Fiction }\end{array}$ & N/A & $\begin{array}{c}\mathrm{J} 940 . \\
5316\end{array}$ \\
\hline $\begin{array}{l}\text { Show Way } \\
\text { (Woodson) }\end{array}$ & $\begin{array}{c}\mathrm{J} \\
\text { Illustrated } \\
\text { Fiction } \\
\end{array}$ & $\begin{array}{l}\text { Picture } \\
\text { Book }\end{array}$ & $\begin{array}{c}\text { Juvenile } \\
\text { Fiction } \\
* * * \\
\end{array}$ & $\mathrm{E}$ & $\mathrm{E}$ & $\mathrm{E}$ & $\begin{array}{l}\text { Picture } \\
\text { Book }\end{array}$ & $\mathrm{E}$ & $\begin{array}{l}\text { Picture } \\
\text { Book }\end{array}$ \\
\hline The Wall (Sís) & J 943.7 & $\begin{array}{l}\text { Children’s } \\
943.7\end{array}$ & N/A & J 943.704 & $\begin{array}{c}\text { Children’s } \\
943 . \\
704092\end{array}$ & J 943 & J 921 & N/A & $\begin{array}{c}\mathrm{J} \\
\text { Biography }\end{array}$ \\
\hline $\begin{array}{l}\text { Watertower } \\
\text { (Crew) }\end{array}$ & N/A & N/A & $\begin{array}{l}\text { Juvenile } \\
\text { Fiction } \\
\text { SciFi / } \\
\text { Fantasy } \\
\end{array}$ & $\mathrm{E}$ & N/A & N/A & $\begin{array}{l}\text { Juvenile } \\
\text { Fiction }\end{array}$ & N/A & N/A \\
\hline $\begin{array}{c}\text { Wee Winnie } \\
\text { Witch's Skinny } \\
\text { (Hamilton) }\end{array}$ & $\begin{array}{c}\mathrm{J} \\
\text { Illustrated } \\
\text { Fiction }\end{array}$ & $\begin{array}{l}\text { Children’s } \\
\text { Fiction }\end{array}$ & $\begin{array}{l}\text { Juvenile } \\
\text { Fiction } \\
\text { Mystery }\end{array}$ & $\begin{array}{l}\text { Juvenile } \\
\text { Fiction }\end{array}$ & $\mathrm{E}$ & $\begin{array}{l}\text { Juvenile } \\
\text { Fiction }\end{array}$ & $\begin{array}{c}\text { Juvenile } \\
\text { Fiction } \\
\text { (Holiday) } \\
* * * *\end{array}$ & N/A & $\begin{array}{l}\text { Juvenile } \\
\text { Fiction }\end{array}$ \\
\hline $\begin{array}{l}\text { Wolves in the } \\
\text { Walls } \\
\text { (Gaiman) }\end{array}$ & $\begin{array}{c}\mathrm{J} \\
\text { Illustrated } \\
\text { Fiction }\end{array}$ & $\begin{array}{c}1 \text { copy in } \\
\text { Picture } \\
\text { Books; } 2 \\
\text { copies in } \\
\text { Children's } \\
\text { Fiction } \\
\end{array}$ & $\begin{array}{l}\text { Juvenile } \\
\text { Fiction } \\
\text { SciFi / } \\
\text { Fantasy }\end{array}$ & $\mathrm{E}$ & $\mathrm{E}$ & $\begin{array}{l}\text { Youth } \\
\text { Graphic } \\
\text { Novel }\end{array}$ & $\begin{array}{l}\text { Juvenile } \\
\text { Fiction }\end{array}$ & $\mathrm{E}$ & $\begin{array}{l}\text { Juvenile } \\
\text { Fiction }\end{array}$ \\
\hline $\begin{array}{l}\text { Woolvs in the } \\
\text { Sitee (Wild) }\end{array}$ & J 398.47 & N/A & N/A & $\mathrm{E}$ & N/A & N/A & N/A & N/A & $\begin{array}{c}\text { Teen } \\
\text { Fiction }\end{array}$ \\
\hline
\end{tabular}

* ICPL has special bins separate from the picture book shelves to house Caldecott winners. Interestingly (and practically), the 2008 winner, The Invention of Hugo Cabret, by Brian Selznick (2007), which is not in the picture book format, will remain housed in the Juvenile Fiction collection.

** DPL (Main) holds an additional copy in its Adult Nonfiction collection, classified at 759.59.

*** DPL classifies this book as Juvenile Fiction, but it exists as part of the Reading Rainbow collection, which also includes Picture Books.

**** RPL keeps this book in its Holiday collection, though it does so with other Juvenile Fiction, rather than with Picture Books. 